\title{
Production and Marketing of Raisins in Vijayapura District - An Economic Analysis
}

\author{
M.G. Kerutagi", A.S. Pavithra and Shweta Byahatti \\ Department of Social \& Allied Sciences, Cost of Cultivation and Market Intelligence Cell, \\ University of Horticultural Sciences, Bagalkot, Karnataka, India \\ *Corresponding author
}

\begin{tabular}{|l|}
\hline Ke y w or d s \\
Raisins processing, \\
Marketing channel, \\
Price spread
\end{tabular}

\section{Introduction}

Grape is one of the important fruit crops grown in tropical India. It is the third most widely cultivated fruit after citrus and banana. Grapes are widely consumed as fresh fruit in India. It is also used for producing raisins, wine, juice, juice concentrate, squash,

\begin{abstract}
A B S T R A C T
A study on production and marketing of raisins in Vijayapura district was carried out during 2016-17 with an objective of analysing the viability in production and marketing of raisins. The study indicated that the cost incurred to produce raw grapes (11.90 tons) from an acre of grape orchard was Rs. 2,04,584.49. The total cost incurred for raisin production from 11.90 tons of raw grapes was Rs. 2,49,769.84. The gross income earned by selling 3.96 tons of raisins were Rs. 5,16,780.00 at a price of Rs. 1,30,500.00 per ton. The cost of processing of raisins estimated at Rs. 63,073.19 per ton and B: C ratio was 2.06. Producers share in consumer's rupee was 54. 08 per cent and producer got net price Rs 1,23,549.90 per ton against the market price of Rs 2,28,450.00 per ton (consumer's price) and price spread was Rs. $1,04,900.10$ per ton. The results revealed that raisin making was economically viable venture. Producers faced the problems like fluctuation in prices, inadequate market facility, expensive infrastructure for processing, lack of cold storage and non-availability of skilled labour. Problems faced by wholesalers were high fluctuation in market price, high cost of transportation and lack of knowledge on market information and in case of retailers' high fluctuation of market price, quality deterioration and lack of market information were major problems. The raisins produced in the study area were of good quality and so efforts should made to export the raisin. However, the basic infrastructure facilities required to export were lacking in the study area. Establishment of efficient market information system and establishment of raisin making units should be encouraged. Government should promote cold storage units and encourage online trading for better price realisation for farmers and better quality raisins to traders at competitive prices.
\end{abstract}

beverages, jams and marmalades. Grapes are highly digestible and have a number of therapeutic properties. The world production of raisin is presently 1.2 million metric tons. Turkey and USA are the largest producer of in the world and together contribute 54.69 per cent. India accounts for 1.20 per cent of the total share of raisins export in the world. 
Maharashtra and Karnataka together contribute about 96.13 per cent of India's grapes production.

Vijayapura district stands first position in grape production in Karnataka state, with an area of 10,582 hectares and 1, 90,856 metric tons of production in 2015-16. There is abundant scope for processing of grapes in the form of raisins in Vijayapura district. Though Vijayapura district is the major grape growing area of Karnataka and the district has been declared as "Horticulture district" by the State Government. But there is no adequate infrastructure and marketing facilities to enable grape growers and raisins production to realize enumerative price. Since export potential is not tapped in the district.

Considering the above mentioned propositions the present research was conducted to study the economic analysis of production and marketing of raisins in Vijayapura district. The study was carried out with the following specific objectives;

The specific objectives of the study are:

To analyse the economic performance of raisin making in the study area.

To identify the marketing channels of raisin marketing and to workout price spread.

To identify the constraints in raisin production and marketing to provide measures to improve.

\section{Hypothesis of the study}

Raisins making is a profitable venture

Marketing channels in raisin marketing are efficient

Price spread in the raisin marketing is high

\section{Materials and Methods}

The study is based on primary data pertaining to the agricultural year 2016-17. For evaluating the specific objectives of the study, important primary data relating to establishment of processing unit, economics of raisin making and marketing of raisin was collected in Vijayapura district by personal interview method with the help of pre-tested schedule and for identifying marketing channel, marketing cost and margin data was collected from various stakeholders like commission agents (5), wholesalers (5), retailers (5). Totally 30 farmers randomly selected to obtain information regarding processing and marketing of raisins. Data was analysed using descriptive statistics.

\section{Concepts used}

$\mathrm{Y}$-Trellis system is the training of grape vines is important as it helps to maintain the stature and spread of the vine in a way that is convenient to carry out the intercultural operations. Various structures that provide support the grapevines are called as trellis. YTrellis system is the ideal economical trellis system which is commonly adopted in the study area.

Plant protection chemicals (PPC) is the cost of different insecticides, weedicides and fungicides used for weed, pest and diseases control was determined on the basis of actual price paid by the farmers

Marketing channel refers to the alternate routes of product flow from the producer to final destiny.

Marketing cost is the cost incurred by the producer-seller during arrival of produce for sale.

Price spread is worked out by computing the differences between the prices received by the producers and prices paid by the consumer. 
Price spread $=\mathrm{Pc}-\mathrm{Pp}$

Where,

$\mathrm{Pc}=$ Price paid by the consumer

$\mathrm{Pp}=$ Price received by the producer

\section{Producer's share in consumer's rupee}

It is the price received by the farmer expressed as a percentage of the retail price (i.e., the price paid by the consumer). If $\mathrm{Pp}$ is the retail price, the producer's share in consumer's rupee (Ps) may be expressed as follows:

$\mathrm{Ps}=(\mathrm{Pp} / \mathrm{Pc})^{*} 100$

Where,

Ps $=$ Producer's share in consumer's rupee

$\mathrm{Pp}=$ Price of the produce received by the farmers

$\mathrm{Pc}=$ Price of the produce paid by the consumer.

\section{Garrett's ranking technique}

To study constraint faced by processors, wholesalers and retailers in raisin marketing Garrett's ranking technique was employed

In order to assess the constraints faced by the raisin producers, whole sellers and retailers in marketing of raisins, the Garrett's ranking technique was used to prioritise the constraints. The order of the merits given by the respondents was changed into ranks by using the following formula

Percent position $=100(\mathrm{Rij}-0.5) / \mathrm{Nj}$ Where,

$\mathrm{Rij}=$ rank given for $\mathrm{i}^{\text {th }}$ factor by $\mathrm{j}^{\text {th }}$ individual .

$\mathrm{Nj}=$ number of factors ranked by $\mathrm{j}^{\text {th }}$ individual.
The percentage position of each rank was converted into scores by referring the table given by Garrett (Garrett and Woodworth, 1969). Then for each factor the scores of individual respondents were added together and divided by the total number of respondents for whom scores were added. These mean scores for all the factors were arranged in descending order and the constraints were ranked.

\section{Results and Discussion}

The results presented in Table 1 indicated that the time required to establish grape orchard was 15 to 18 months. The per acre establishment cost of grape orchard was Rs. $2,67,342.00$. The value of wire ( $\mathrm{Y}$ trellis system) was the major item of establishment cost accounting for Rs. 67,020.69 (25.07 per cent) followed by stone pillars Rs. 48,161.89 (18.02 per cent), bore well Rs. 38,808 (14.52 per cent), drip irrigation system Rs. 30,187.73 (11.29 per cent), pump set Rs. 25,571.35 (9.57 per cent), sprayer Rs. 18,500 (6.92 per cent), plantation Rs. 10,640.56 (3.98 per cent) and others accounted to percent. The results of the study are in line with the research conducted by Naveen (2009). It was revealed that the wire (Y trellis), stone pillars and bore well cost was maximum in total establishment cost.

Cost structure in grape cultivation is presented in Table 2. Total cost of cultivation of grapes per acre was Rs. 2,04,584.49 of which share of variable cost was 75.17 per cent and fixed cost was 24.83 per cent. In the total cost of cultivation, proportion of variable cost was Rs. $1,53,790.83$ which was actual paid out cost by the farmers. Among the variable costs, the share of human labour cost was maximum (34.08 per cent) followed by plant protection chemicals 22.80 per cent (Rs. 35,067. 20) and micronutrients accounted for 17.08 per cent (Rs. 26,260). Human labour cost was higher compared to other operational cost items, the 
results are similar to the results of the study on economics of grape production in Marathwada region of Maharashtra state conducted by Kamble et al., (2014). Total fixed cost was Rs. $50,793.66$, of the fixed cost, the share of major cost items were amortized establishment cost accounted to 35.17 per cent (Rs.17,862.67) fallowed by managerial cost accounted to 32.46 per cent (Rs.16,488.03). Rental value of land and interest on fixed cost was 20.18 per cent (Rs.10,250) and 10.54 per cent (Rs.5,353.52) respectively. On an average 11.90 tons of output was obtained from an acre of grape orchard. Cost of production of grape was Rs. 17,191.97 per ton and cost of production over variable cost was Rs.12,923.59 per ton.

It is observed from the Table 1 and 2 the establishment and production cost was high. Usage of improved technologies like machine for digging of pits, battery operated neumatic secateurs for pruning and power tiller or rotavator for weeding in grape cultivation is possible to save not only time but also helps to reduce production cost.

\section{Processing of raisins}

Processing of raisins mainly concerned with the increase in utilities (from fresh grapes to raisin by creating form utility in it). Dried grapes, commonly known as raisin, have a greater economic importance including many countries (Pangav, 2002). Results of the study conducted by Pangav (2002) proved that better returns to growers by producing raisins rather than production of grapes. Cost of establishment of raisin making unit presented in Table 3. The total cost of establishment raisin making unit in $900 \mathrm{sq} \mathrm{ft}$ was Rs. $1,15,794.34$. The cost involved in construction of processing shed was more (Rs. 83,500) followed by covering net Rs. $(20,585.5)$ and crates (Rs 11,708.84). The raisin making unit investment cost on processing shed was higher than the investment in other capital assets. Hence, there is a need to evolve cost effective shed for the benefit of processors.

The cost incurred for raisin production by oil dipping method is presented in Table 4. The total cost required for raisin production from 11.90 tons (one acre of land) of raw grapes was Rs. 2,49,769.84 out of which variable costs accounted to Rs. 2,41,082.12 (96.52\%) and fixed costs accounted to Rs. 8,687.71 $(3.48 \%)$. This indicated that the proportion of variable cost was higher than the fixed cost. The variable cost in oil dipping method was low compared to sulphur fumigation method (Kakkali, 2013). The division of variable cost into various constituent revealed that raw material (raw grape) cost was more which was Rs. 2,04,584.49 (84.86\%), cost of production of raw grapes was taken as raw material cost, followed by interest on working capital was Rs. 31,445.49 (13.04\%) worked out at 15 per cent. Chemical cost was Rs. 3,088.80 (1.28\%) and labour charge was Rs. 1,901.25 (0.79\%).

The present study expressed that the raw grapes cost was higher among variable cost and human labour accounted less cost than other inputs in the processing. The results of the present study are similar to study conducted by Kakkali (2013), the study reported that the labour cost in oil dipping method of raisin production was less compared to sulphur fumigation method of raisin production because in oil dipping method the number of days require to produce raisin was less as compare to sulphur fumigation method. Among the fixed costs the share of amortization and interest on fixed cost was Rs. 7,756.89 (89.29 \%) and Rs. $930.82(10.71 \%)$ respectively.

Returns structure in raisin production is represented in Table 5, it was observed that the gross income earned by selling of 3.96 tons of raisins was Rs. 5,16,780.00 at price of 
Rs. 1,30,500.00 per ton. The Gross profit and net profit was obtained Rs. 2,75,697.87 and Rs. 2,67,010.20 respectively and net return per ton of raisins was Rs. $67,426.81$.

Cost of processing of raisins estimated at Rs. 63,073.19 per ton. The per ton processing cost in present study is higher than the per ton processing cost in earlier study conducted by Babar et al., (2004).

The cost of raisin grape production was 48 per cent less than that table grape production but benefit was higher than that of table grape (Gaikwad, 2005). The Benefit -Cost ratio of the present study was (2.06) greater than unity. The another study conducted by Kakkali (2013) and Koli (2013), reported that $\mathrm{B}$ : $\mathrm{C}$ ratio was 1.18 and 1.98 which is lesser than the present study.

There by indicating that raisin making is economically viable venture. The study conducted by Appasmandri et al., (2017) reported that net returns received by the marketing of grapes (table purpose) per hectare was Rs.2,13,038.00 which is lesser than the net returns received by the marketing of raisins (Rs. 2,67,010.20 per acre). These results suggested that the maximum quantity of grapes should be diverted for raisin making which gave additional benefits to the producers.

The result witnessed that the raisin processing is profitable venture. The foregoing analysis revealed that in order to reap the benefits and to achieve efficiency of processing units, it is necessary to undertake the production of grapes for only raisin purpose. Hence, the hypothesis of processing of raisins is profitable has been accepted.

\section{Marketing of raisins}

The marketing of raisins was studied in Vijayapura market because more number of farmers from this area was selling their produce in the same market and this is the major raisin market in Karnataka.

The cost of marketing of one ton of raisins is presented in the Table 6 and figure 1 . The total marketing cost per ton of raisins was estimated to Rs. 6,950.12 for processors.

Among these cost market commission was more (Rs. 2,610.00) followed by packaging material cost (Rs. 1,433.19), grading (Rs. 1,386.24), transportation cost (Rs. 860.00), rent of cold storage (Rs. 373.73) and loading and unloading charges (Rs. 286.96). The market commission, packaging material and grading cost together shared 78.11 per cent of total cost of raisin marketing. These results are higher compared to earlier study conducted by Sharnesh (1994) and Kakkali (2013) in raisin production. It is due to increasing service cost over the years. This calls for initiating control measure on part of the government to regulate the activities of commission agents and to reduce the commission charges to safeguard the interest of the producers, besides creating infrastructure facilities for transport of raisin to distant markets. It is noticed that all the cost incurred in the processing and marketing of raisins accounted to major cost for processors for their produce.

\section{Channels involved in marketing of raisins}

The study during investigation identified single marketing channel through which raisin usually marketed in the study area is as follows,

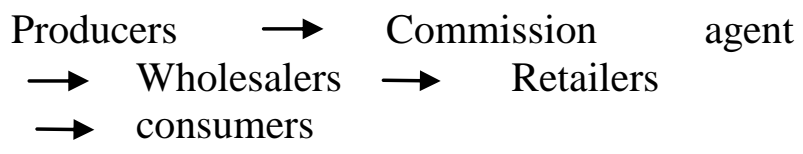

The study reported that the single marketing channel was observed in Vijayapur district for raisin. The observation was same from the earlier study conducted by Satihal (1993) for 
ber crop. The channel revealed that the raisins are transported to the nearby market and product sold through commission agent to wholesaler and wholesaler after purchase transport it to the nearest market and sell it to the retailer and finally the consumer purchases product from the retail market.

A perusal from the Table 7 reveals that the price spread, marketing margin and producer share in consumer's rupee. This channel, price spread was worked out to be Rs. 1,04,900.10 per ton. Producers incurred marketing cost for selling of raisin was Rs. 6,950.12 per ton and producer got Rs. 1,23,549.90 against the market price Rs 1,30,500.00 per ton. In this channel the commission agent fix the price in auction centre on behalf of producer and wholesalers for those commission agent charges 2 per cent of market commission and most of the raisin producers preferred this channel even though market commission was involved.

Marketing cost incurred by the commission agent, wholesalers and retailers was Rs. 3,262.50, Rs. 4,226.52 and Rs. 4,454.14 per ton respectively. The significant item of marketing cost was commission and transportation charges. The total marketing charges incurred by all stakeholders in this channel was Rs. 18,893.28 per ton. The results is more compared to the earlier study conducted by Kakkali (2013) mentioned that the total marketing cost worked out for this channel was Rs. 12,448 per ton.

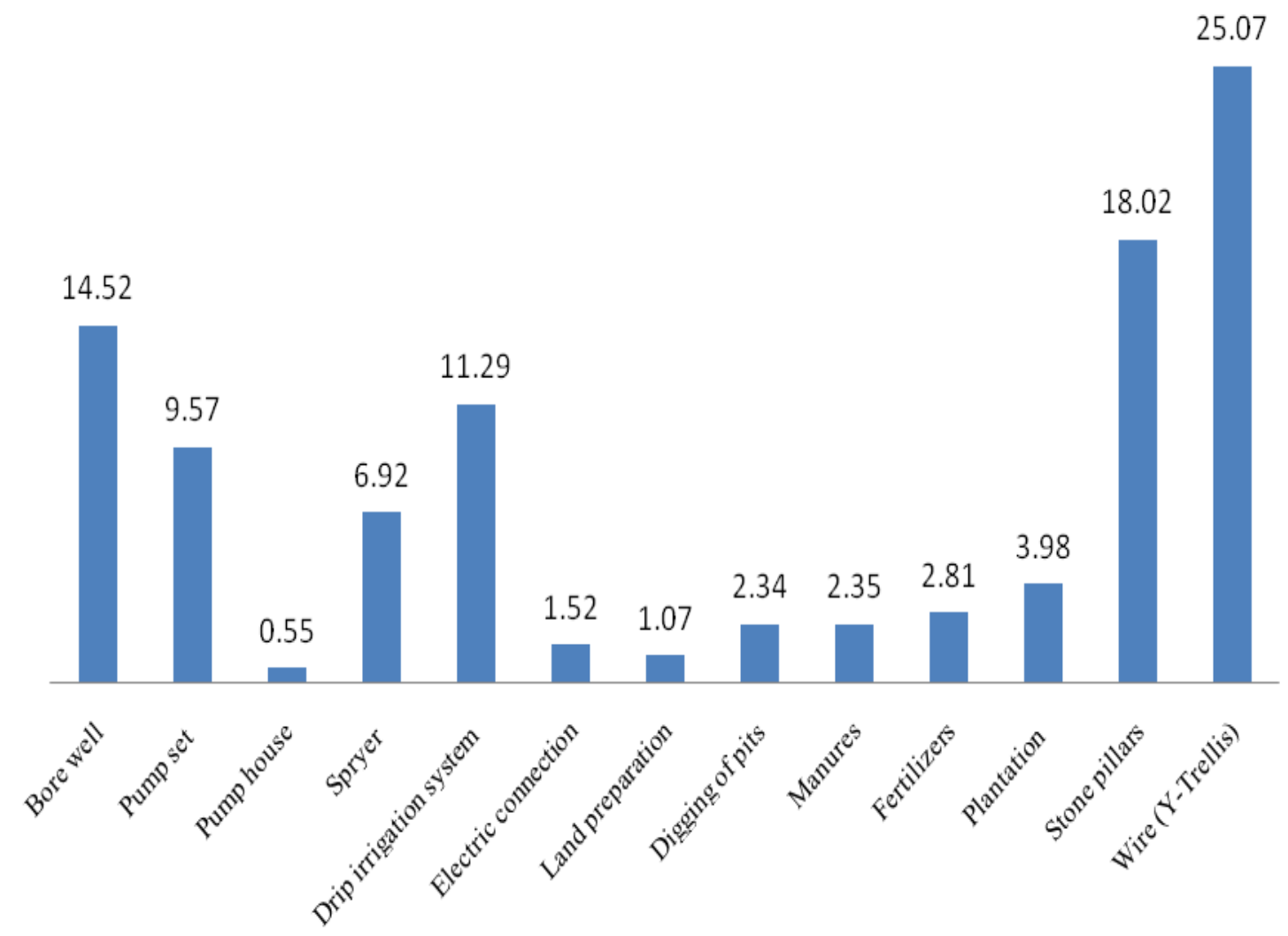

Establishment cost of grapes orchard (\%) 
Fig.1 Cost of marketing of raisin by the processors

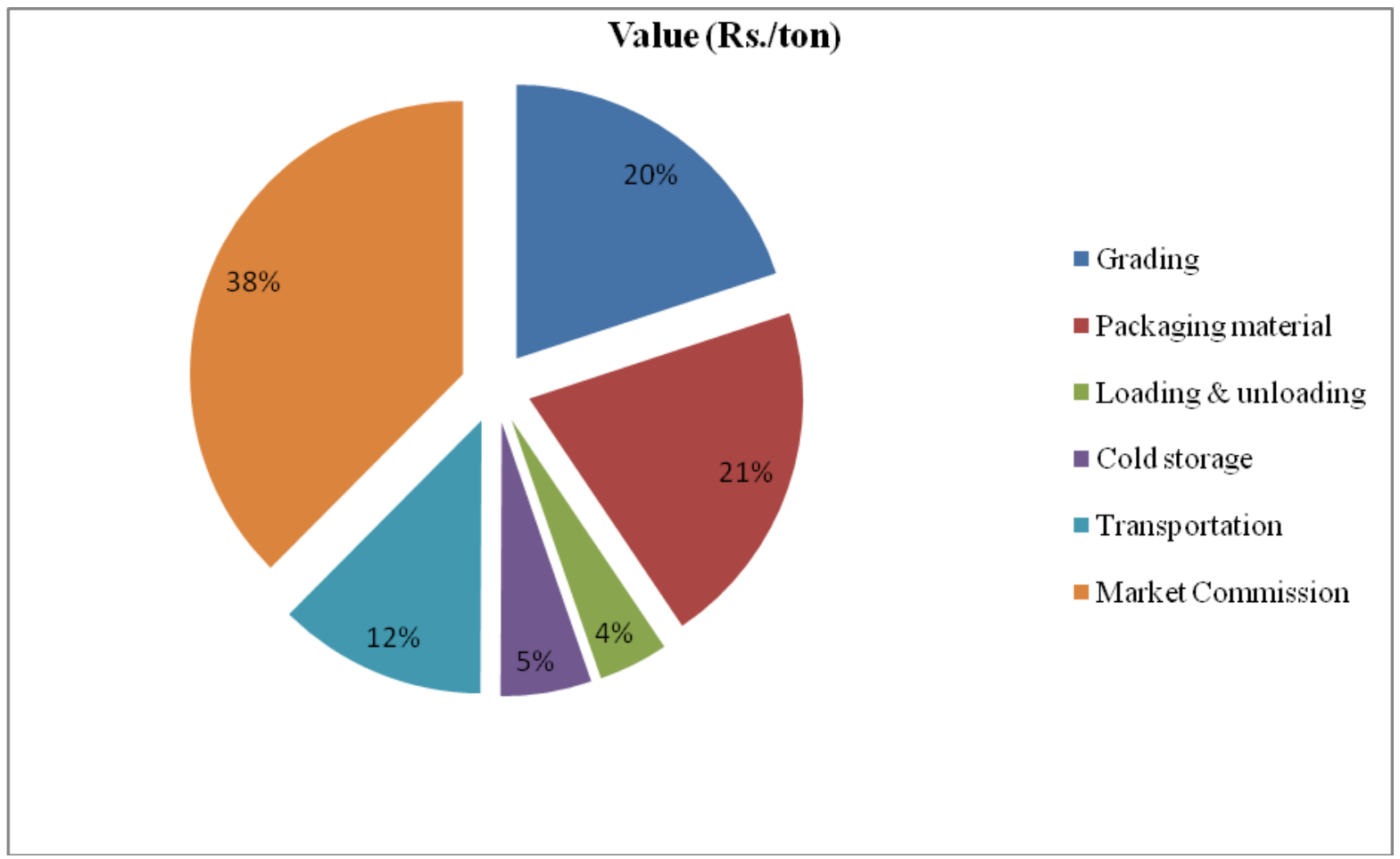

Table.1 Establishment cost of grape orchard (Rs/acre) in the study area

\begin{tabular}{|l|l|r|r|}
\hline \multicolumn{1}{|c|}{ S. No } & \multicolumn{1}{|c|}{ Cost } & \% \\
\hline 1 & Bore well & $38,808.00$ & 14.52 \\
\hline $\mathbf{1}$ & Pump set & $25,571.35$ & 9.57 \\
\hline $\mathbf{3}$ & Pump house & $1,482.00$ & 0.55 \\
\hline $\mathbf{4}$ & Spryer & $18,500.00$ & 6.92 \\
\hline $\mathbf{5}$ & Drip irrigation system & $30,187.73$ & 11.29 \\
\hline $\mathbf{6}$ & Electric connection & $4,069.63$ & 1.52 \\
\hline $\mathbf{7}$ & Land preparation & $2,860.00$ & 1.07 \\
\hline $\mathbf{8}$ & Digging of pits & $6,244.36$ & 2.34 \\
\hline $\mathbf{9}$ & Manures & $6,271.10$ & 2.35 \\
\hline 10 & Fertilizers & $7,524.99$ & 2.81 \\
\hline 11 & Plantation & $10,640.56$ & 3.98 \\
\hline 12 & Stone pillars & $48,161.89$ & 18.02 \\
\hline 13 & Wire (Y-Trellis) & $67,020.69$ & 25.07 \\
\hline & Total establishment cost & $2,67,342$ & 100 \\
\hline
\end{tabular}


Table. 2 Cost of production of grapes (Rs./acre) in the study area

\begin{tabular}{|c|c|c|c|c|}
\hline SI. No & Particulars & Quantity & Cost & $\%$ \\
\hline & Human labour (man days) & & & \\
\hline \multirow[t]{4}{*}{1.} & Family Male (no.) & 79.50 & $23,585.27$ & 11.53 \\
\hline & Female (no.) & 8.00 & 1536.32 & 0.75 \\
\hline & Male (no.) & 43.45 & $12,890.31$ & 6.30 \\
\hline & Female (no.) & 75.00 & $14,403.00$ & 7.04 \\
\hline 2. & Machine (Hrs) & 2.50 & $1,209.25$ & 0.59 \\
\hline 3. & Sprayer (days) & 25.50 & $3,187.50$ & 1.56 \\
\hline 4. & FYM(Tractor loads) & 2.30 & $5,624.75$ & 2.75 \\
\hline 5. & Fertilizer (Qtl) & & $9,967.56$ & 4.87 \\
\hline 6. & Micronutrient & & $26,260.00$ & 12.84 \\
\hline 7. & PPC & & $35,067.20$ & 17.14 \\
\hline 8. & Interest on working capital (15\%) & & $20,059.67$ & 9.81 \\
\hline \multirow[t]{2}{*}{ A } & Total variable cost & & $1,53,790.83$ & 75.17 \\
\hline & Fixed cost & & & \\
\hline 1. & Land and water tax & & 12.00 & 0.01 \\
\hline 2. & $\begin{array}{l}\text { Depreciation on farm machinery and farm } \\
\text { buildings }\end{array}$ & & 827.44 & 0.40 \\
\hline 3. & Rental value of land & & $10,250.00$ & 5.01 \\
\hline 4. & Interest on Fixed Cost (12\%) & & $5,353.52$ & 2.62 \\
\hline 5. & Amortized Establishment Cost & & $17,862.67$ & 8.73 \\
\hline 6. & Managerial cost $(10 \%$ of all cost $)$ & & $16,488.03$ & 8.06 \\
\hline$\overline{\mathbf{B}}$ & Total fixed cost & & $50,793.66$ & 24.83 \\
\hline C & Total cost & & $2,04,584.49$ & 100.00 \\
\hline D & Yield of grapes (ton/acre) & & 11.90 & \\
\hline $\mathbf{E}$ & Cost of production over total cost (Rs/ton) & & $17,191.97$ & \\
\hline T & Cost of production over variable cost (Rs/ton) & & $12,923.59$ & \\
\hline
\end{tabular}

Table.3 Cost of establishment of raisin making unit (900 sq ft)

\begin{tabular}{|l|l|r|}
\hline SI. No & Capital investment & Value (Rs.) \\
\hline 1. & Processing shed & 83,500 \\
& & $(72.11)$ \\
\hline 2. & Covering net & $20,585.5$ \\
\hline 3. & Crates & $(17.77)$ \\
\hline & Total & $11,708.84$ \\
& & $(10.11)$ \\
\hline
\end{tabular}

Note: Figures in parenthesis indicate percentage to the total 
Table.4 Cost structure of raisin processing (Rs./acre)

\begin{tabular}{|c|c|c|c|c|}
\hline \multirow[t]{2}{*}{ SI. No } & \multirow[t]{2}{*}{ Particulars } & \multicolumn{3}{|c|}{ Vijayapura District } \\
\hline & & Quantity & Cost & $\%$ \\
\hline & Variable Cost & & & \\
\hline 1. & Labour cost (man days) & 7.00 & 1901.25 & 0.76 \\
\hline 2. & Raw grapes (tons) & 11.90 & $2,04,584.49$ & 81.91 \\
\hline 3. & Chemicals (litres) & 22.00 & 3088.8 & 1.24 \\
\hline 4. & Sprayer (days) & 0.74 & 62.09 & 0.02 \\
\hline 5. & $\begin{array}{l}\text { Interest on working capital } \\
(15 \%)\end{array}$ & & $31,445.49$ & 12.59 \\
\hline 6. & Total Variable cost & & $2,41,082.12$ & 96.52 \\
\hline & Fixed Cost & & & \\
\hline 7. & Amortized establishment cost & & 7756.89 & 3.11 \\
\hline 8. & Interest on fixed cost (12\%) & & 930.82 & 0.37 \\
\hline 9. & Total Fixed Cost & & 8687.71 & 3.48 \\
\hline 10. & Total cost & & $2,49,769.84$ & 100 \\
\hline
\end{tabular}

Table.5 Returns structure in raisin processing

\begin{tabular}{|l|l|r|}
\hline SI. No & \multicolumn{1}{|c|}{ Particulars } & \multicolumn{2}{|c|}{ Value } \\
\hline 1. & Cost of processing of raisins (Rs./Acre) & $2,49,769.84$ \\
\hline 2. & Raisins (tons/acre) & 3.96 \\
\hline 3. & Price (per ton) & $1,30,500.00$ \\
\hline 4. & Gross income & $5,16,780.00$ \\
\hline 5. & Gross profit & $2,75,697.87$ \\
\hline 6. & Net Profit & $2,67,010.20$ \\
\hline 7. & Net return per ton of raisins & $67,426.81$ \\
\hline 8. & Cost of processing (Rs/ton) & $63,073.19$ \\
\hline 9. & B:C ratio & 2.06 \\
\hline
\end{tabular}

Table.6 Cost of marketing of raisins by the processors

\begin{tabular}{|l|l|r|}
\hline \multicolumn{1}{|c|}{ SI. No } & \multicolumn{1}{|c|}{ Particulars } & Value (Rs. / ton) \\
\hline 1. & Grading & 1386.24 \\
\hline 2. & Packaging material & 1433.19 \\
\hline 3. & Loading \& unloading & 286.96 \\
\hline 4. & Cold storage (per month) & 373.73 \\
\hline 5. & Transportation & 860.00 \\
\hline 6. & Market Commission & 2610.00 \\
\hline & Total & 6950.12 \\
\hline
\end{tabular}


Table.7 Price spread in raisins marketing channel (Rs/tonne)

\begin{tabular}{|c|c|c|}
\hline Sl. No & Particulars & Amount \\
\hline 1 & Producers price & $1,30,500.00$ \\
\hline \multirow[t]{7}{*}{2} & Marketing Charges incurred by producers & \\
\hline & Grading & 1386.24 \\
\hline & Packaging material & 1433.19 \\
\hline & Loading \& unloading & 286.96 \\
\hline & Cold storage rent (per month) & 373.73 \\
\hline & Transportation charges & 860.00 \\
\hline & Market Commission & 2610.00 \\
\hline 3 & Total marketing charges incurred by the producer & 6950.12 \\
\hline 4 & Net amount received by producers & $1,23,549.90$ \\
\hline \multirow[t]{4}{*}{5} & $\begin{array}{l}\text { Marketing charges incurred by the commission } \\
\text { agent }\end{array}$ & \\
\hline & Purchase price & $1,30,500$ \\
\hline & Commission & $3,262.50$ \\
\hline & Sale price & $1,33,762.50$ \\
\hline \multirow[t]{6}{*}{6} & Marketing charges incurred by the wholesaler & \\
\hline & Purchase price & $1,33,762.50$ \\
\hline & Commission charge & 2675.25 \\
\hline & Loading and unloading & 366.47 \\
\hline & Transportation charges & 784.80 \\
\hline & Cold storage rent/ month & 400.00 \\
\hline 7 & Total marketing charges incurred by the wholesaler & 4226.52 \\
\hline 8 & Marketing margin of the wholesaler & $34,778.25$ \\
\hline 9 & wholesaler price & $1,68,540.75$ \\
\hline \multirow[t]{5}{*}{10} & Marketing charges incurred by the retailer & \\
\hline & Purchase price & $1,68,540.75$ \\
\hline & Commission charge & 3370.81 \\
\hline & Loading and unloading & 360.00 \\
\hline & Transportation charges & 723.33 \\
\hline 11 & Total marketing cost incurred by the retailer & 4454.14 \\
\hline 12 & Marketing margin of the retailer & $59,909.25$ \\
\hline 13 & Consumer price & $2,28,450.00$ \\
\hline 14 & Total marketing cost & $18,893.28$ \\
\hline 15 & Total marketing margin & $94,687.50$ \\
\hline 16 & Price spread & $1,04,900.10$ \\
\hline 17 & Producers share in consumer's rupee (\%) & 54.08 \\
\hline
\end{tabular}


Table.8 Constraints faced by producers in grapes production

\begin{tabular}{|r|l|r|r|}
\hline Sl. No & Constraints & Mean Score & Rank \\
\hline $\mathbf{1}$ & High cost of establishment & 69.8 & I \\
\hline $\mathbf{2}$ & Lack of capital & 60 & II \\
\hline $\mathbf{3}$ & High cost of inputs & 59.2 & III \\
\hline $\mathbf{4}$ & High incidence of pest and disease & 55.8 & IV \\
\hline $\mathbf{5}$ & Lack of technical guidance & 50.2 & V \\
\hline $\mathbf{6}$ & Non availability of water & 47.4 & VI \\
\hline $\mathbf{7}$ & Non -availability of quality planting materials & 31.2 & VII \\
\hline $\mathbf{8}$ & Lack of quality plant protection chemical & 22.4 & VIII \\
\hline
\end{tabular}

Table.9 Constraints faced by raisin producers

\begin{tabular}{|l|l|r|r|}
\hline \multicolumn{1}{|c|}{ Constraints } & Mean score & Rank \\
\hline 1. & High fluctuation in prices & 81.25 & I \\
\hline 2. & Inadequate market facilities & 74.85 & II \\
\hline 3. & Expensive infrastructure for processing & 66.4 & III \\
\hline 4. & Lack of cold storage facilities & 61.9 & IV \\
\hline 5. & Non availability of skilled labours & 55.2 & V \\
\hline 6. & Inadequate marketing organizations & 55 & VI \\
\hline 7. & Non availability of quality packing material & 46.9 & VII \\
\hline 8. & Lack quality chemicals & 45.7 & VIII \\
\hline 9. & Lack of awareness of grading & 39 & IX \\
\hline 10. & Lack of technology & 32.8 & X \\
\hline 11. & Lack of schemes for raisin marketing and development & 27.35 & XI \\
\hline 12. & Lack of government and technical assistance to farmers & 20.85 & XII \\
\hline
\end{tabular}

Table.10 Constraints faced by wholesalers

\begin{tabular}{|l|l|r|r|}
\hline \multicolumn{1}{|c|}{ Constraints } & Mean score & Ranking \\
\hline 1. & High fluctuation in market price & 76.2 & I \\
\hline 2. & High cost of transportation & 72.6 & II \\
\hline 3. & Lack of market information & 67.2 & III \\
\hline 4. & Lack of transportation facility & 54.8 & IV \\
\hline 5. & Distant market place & 51.8 & V \\
\hline 6. & Inability to grade the produce & 42 & VI \\
\hline 7. & High commission charges & 33.6 & VII \\
\hline 8. & Lack of labour availability during loading and unloading & 33.2 & VIII \\
\hline 9. & Lack of infrastructure facility in the market & 27.2 & IX \\
\hline
\end{tabular}


Table.11 Constraints faced by retailers

\begin{tabular}{|l|l|r|r|}
\hline SI. No & \multicolumn{1}{|c|}{ Constraints } & Mean score & Rank \\
\hline 1. & High fluctuation in market price & 80 & I \\
\hline $\mathbf{2 .}$ & High cost of transportation & 69.6 & II \\
\hline $\mathbf{3 .}$ & Lack of market information & 67.4 & III \\
\hline $\mathbf{4 .}$ & Lack of transportation facility & 59 & IV \\
\hline $\mathbf{5 .}$ & Quality deterioration & 53 & V \\
\hline 6. & Inability to grade the produce & 51.2 & VI \\
\hline 7. & High commission charges & 42 & VII \\
\hline $\mathbf{8 .}$ & Lack of labour availability during loading and unloading & 39.6 & VIII \\
\hline $\mathbf{9 .}$ & Discoloration of product & 28.8 & IX \\
\hline 10. & Storage loss & 25.4 & X \\
\hline
\end{tabular}

The retailer incurred marketing cost Rs. 4,454.14 and earned profit margin of Rs. $59,909.25$ per ton. Retailer sell the produce to consumer at the price of Rs. 2,28,450.00 per ton. The retailer gained more marketing margin than any other intermediaries in the market chain. The study witnessed that the presence of commission agents in marketing channel is one of the important reason for farmers to not receiving good price for their produce. To stop the intervention of commission agent activities it is necessary for government to initiate the online trading service to ensure better price for raisin farmers. It helps to connect direct link between farmers and traders by shortening the marketing channel.

\section{Producer's share in consumer's rupee}

Table 7 represents price spread in raisins marketing. The producer could realize 54.08 per cent of the consumer price with a net price Rs. $1,23,549.90$ per ton. The rest 45.92 per cent was comprised of marketing cost and profit margin of the market functionaries. The results revealed that the producer share in consumer rupee was lower than the earlier study conducted by Kakkali (2013). Hence, the hypothesis of price spread in raisin marketing is high has been accepted.
Constraints in raisin processing and marketing

Major constraints experienced in the production of grapes by grapes grower is presented in Table 8. Among these constraints farmers opined that high cost of establishment of grape orchard, lack of capital, high cost of inputs, high incidence of pest and disease and lack of technical guidance are the major constraints faced by the grape growers in the study area. Non availability of sufficient water, non-availability of quality planting materials and lack of quality plant protection chemicals has been the least opined constraints by the farmers in the study area.

The results of the study are in line with the research conducted by Mokashi (2012). It was revealed that high cost of establishment, lack of capital, Maintenance problem of irrigation structures, high cost of inputs and lack of technical guidance were recognised as the major constraints faced by grapes growers.

Table 9 indicates constraints faced by raisin producers. Raisin producers opined that fluctuation in price, inadequate market facility, expensive infrastructure for processing and lack of cold storage and nonavailability of skilled labour were considered 
as major problems. High fluctuation in price was their main concern. Inadequate marketing organization, non-availability of quality packing material constraints were least expressed by the producers.

The results of the study is similar with the research conducted by Ingavale (2001) pointed out the major problems faced by the raisin producers in production were non-availability and high charges of labour, high cost of establishment of raisin making unit. To overcome these problems it is necessary to evolve cost effective infrastructure for raisin processing, providing market facility in raisin production area and should make available of quality chemicals to raisin processors.

Constraints faced by wholesalers were presented in Table 10 based on order of importance. Respondents ranked nine factors identified as major constraints and they categorized them into nine distinct classes. According to raisin wholesalers high fluctuation of market price, high transportation cost and lack of market information were considered as major problems and ranked I, II and III respectively.

It was evident from the Table 10 that, the fluctuation in market price was reported as the major constraint for wholesaler in the study area. Varied production of raisin over the year was a major constraint faced by the market participants. The Kakkali (2013) reported that high fluctuation in market price and high costs of transportation were the major problems faced by wholesalers in the same study area.

Table 11 represents constraints faced by retailers. Majority of the respondents expressed the problem in the fluctuation of market price followed by high cost of transportation and lack of market information in the study area. It was observed that most of the retailers expressed the discoloration of produce and storage loss were the minor problems and they have been assigned lower ranks followed by lack of labour availability for loading and unloading of produce. The results are similar to results of study conducted by Kakkali (2013), expressed that fluctuation of market price, lack of market information and lack of transportation facility were ranked as major problem faced by retailers in Vijaypura.

\section{Policy implications}

The study emphasised that the returns were high in preparation of raisin, hence there is a need to establish more raisin making units in the study area by giving incentives to farmers as it involves more investment.

Processors should concentrate on improved harvesting and processing methods which can result in lower wastages and improved quality as there was more wastages.

Government should promote cold storage units and encourage online trading of raisin for better price.

Establishment of efficient market information system is essential, which provide timely information regarding prices prevailing, demand and current supply in different markets at different time periods in different markets of India. Since farmers were lacking those information.

The present study is intended to depict the production and marketing of raisin in Vijayapura district, the prominent raisin producing district in Karnataka state. The results indicated that the raisin making is profitable venture. The study suggested that the maximum quantity of grapes should be diverted for raisin making which gave additional benefits to the producers. Price spread in this marketing channel was Rs. 1,04,900.10 and producer's share in consumer's rupee was 54.08 per cent. Producer incurred more marketing cost in the channel (Rs. 6,950.12) and retailers received more marketing margin than any other intermediaries in the marketing chain. The majority of the producer expressed that fluctuation of price, inadequate market facility 
were the major constraints, also fluctuation of market price, high cost of transportation and lack of market information were also major problems expressed by the intermediaries. To overcome these problems government should take measure to regulate the activities of commission agents and establish efficient market information system. Government can promote cold storage units and encourage online trading for better price realisation for farmers and better quality raisins to traders at competitive prices.

\section{References}

Appasmandri, S., M. Anjugam, M. Sathaiah and Muthuraja, B. 2017. Production and profitability analysis of grapevine orchard in Coimbatore, Tamil Nadu, India. Int.J.Curr.Microbiol.App.Sci. 6(7): 21722180.

Babar, V.S., A.L., Pharande, G.K., Bembalkar and R.S., Dange, 2004. Economics of production and marketing of raisins in Solapur district. AGRESCO Report, Department of Agricultural Economics, M.P.K.V., Rahuri.

Gaikwad, S. D., 2005, Grapevine cultivation in Sangli District of Maharashtra: A Geographical Analysis unpublished PhD thesis submitted to Shivaji University, Kolhapur.

Horticulture crop statistics of Karnataka state at a glance 2015-16

Ingavale, S.S. 2001. Economics of production and marketing of raisins in Sangli district. M.Sc. (Agri.) Thesis (Unpublished) Submitted to Department of Agricultural Economics, M.P.K.V., Rahuri.
Kakkali, M., 2013, A study on marketing of raisin in Bijapur district, Project Report submitted to the UAS, Bangalore.

Kamble, S.H., R.A., Kolambkar, Chavan, R.V. and Patil, S.P., 2014, Economics of grape production in Marathwada region of Maharashtra state. Internat. Res. J. Agric. Eco. \& Stat., 5 (2): 179-183

Koli, V.H. 2013, Economic analysis of production and marketing of raisins in western Maharastra unpublished M.Sc thesis submitted to Mahatma Phule Krishi Vidyapeeth, Rahuri.

Mokashi P. K., 2012. An economic analysis of export potential of grapes from northern Karnataka. M.Sc. (Agri.) Thesis (Unpublished) Submitted to University of Agricultural Sciences, Dharwad.

Naveen, B.S., 2009, Economics of production and value addition to wine grapes in Bijapur district of Karnataka unpublished M.Sc thesis submitted to University of Agricultural Sciences, Dharwad.

Pangav Sawhney, 2002, Harvest date and postharvest alkaline treatment effects on quantity and quality of Kashmir, Iran, green raisin k. Arzani1, a. H. Sherafaty2, and $\mathrm{m}$. Koushesh-saba, 13.

Sathihal, D.G., 1993, Economics of production and marketing of ber in Bijapur district. Karnataka. M.Sc. (Agri.) Thesis, Univ. Agril. Sci., Dharwad.

Sharnesh, S.H., 1994. Economics of production and processing of grapes in Bijapur district, Karnataka, M.Sc. (Agri.) Thesis (Unpublished) Submitted to University of Agricultural Sciences, Dharwad.

\section{How to cite this article:}

Kerutagi, M.G., A.S. Pavithra and Shweta Byahatti. 2018. Production and Marketing of Raisins in Vijayapura District - An Economic Analysis. Int.J.Curr.Microbiol.App.Sci. 7(09): 658-671. doi: https://doi.org/10.20546/ijcmas.2018.709.078 